INFO ARTIKEL

Riwayat Artikel:

Diterima : 1 Agustus 2019

Disetujui : 15 Agustus 2019

\title{
PENDIDIKAN
}

\section{PENGARUH PENGGUNAAN EDMODO DENGAN METODE BLENDED LEARNING TERHADAP SOFTSKILL DISIPLIN MAHASISWA PENDIDIKAN GEOGRAFI}

\author{
Murjainah $^{1}$, Kiki Aryaningrum ${ }^{1}$, Arisman $^{2}$ \\ ${ }^{1}$ Program Studi Pendidikan Geografi, ${ }^{2}$ Program Studi Pendidikan Olahraga, Universitas PGRI \\ Palembang \\ (区) Murjainah@gmail.com ${ }^{1}$, kikiaryaningrum@gmail.com ${ }^{1}$, Arisman9001@ gmail.com²
}

\begin{abstract}
ABSTRAK
Tujuan dalam penelitian ini adalah untuk mengetahui pengaruh pengunaan Edmodo dengan metode terhadap Softskill displin mahasiswa pendidikan geografi. Batasan persamalahan dalam penelitian ini adalah kedisiplinan mahasiswa dalam menyelesaikan tugas dengan menggunakan fitur tugas Edmodo. Metode penelitian yang digunakan dalam penelitian ini adalah penelitian kuantitatif. Sampel yang digunakan dalam penelitian ini adalah mahasiswa yang mengikuti mata kuliah Media Pembelajaran Berbasis ICT di semester genap, yaitu kelas 4A. Teknik pengumpulan data yang digunakan adalah Dokumentasi dan angket. Analisis data mengunakan analisis Uji T. Hasil penelitian menunjukkan bahwa Setelah dilaksanakan pembelajaran melalui penggunaan Edmodo dengan metode Blended Learning menunjukkan bahwa terdapat pengaruh terhadap Softskill disiplin mahasiswa pendidikan geografi yang ditujukkan dengan $t$ tabel pada DF $36=1,68830$. Maka $t_{\text {hitung }}(6,955)>t_{\text {tabel }}(1,68830)$ dan signifikansi $(2-$ tailed) dengan nilai probabilitas/p value uji T Paired menunjukkan hasil $=0,000$ dan nilai $\mathrm{p}$ value $(0,000)$ $>0,05$ (95\% tingkat kepercayaan).
\end{abstract}

Kata Kunci: Blended Learning, Softskill, Disiplin, ICT.

\section{PENDAHULUAN}

Dalam perencanaan pembelajaran terdapat tiga faktor yang harus diperhatikan, yakni kondisi pembelajaran, metode pembelajaran dan hasil pembelajaran. Dari ketiga faktor tersebut, metode pembelajaran merupakan faktor yang paling bisa dimodifikasi oleh guru. Dalam metode pembelajaran, guru dapat menggunakan beragam cara untuk bisa mencapai hasil pembelajaran yang sesuai dengan kondisi pembelajaran, termasuk dalam pemilihan media pembelajaran yang sesuai dengan kebutuhan pelajaran (Uno, 2008). Selain media yang disesuaikan dengan kebutuhan pelajaran dikelas, perlu juga menyesuaikan dengan kebutuhan pembelajar dalam proses pembelajaran sehingga tercapainya tujuan pembelajaran di era ini, pemanfaatan teknologi dalam proses pembelajaran.

Teknologi menjadi salah satu sarana penting bagi dosen untuk mendukung pelaksanaan pembelajaran di kelas yang memusatkan pembelajaran kepada pembelajar dan memberikan pengaruh kepada kemampuan mahasiswa. Penggunaan teknologi dalam pembelajaran memberikan pengaruh terhadap kemampuan mahasiswa dalam membuat peta berbasis Arcgis (Murjainah \& Utomo, 2018). Ini menunjukkan bahwa pelaksanaan pembelajaran yang berpusat kepada mahasiswa memungkinkan mempengaruhi potensi yang mendukung mahasiswa dalam mengembangkan Hardskill dan Softkill. Potensi itu menjadi hal penting bagi mahasiswa untuk bekal 
bagi mahasiswa memasuki dunia kerja. Ini sejalan dengan Manara (2014) mengungkapkan bahwa soft skill sangat dibutuhkan dalam dunia kerja. Kemampuan ini dapat membantu individu menerapkan pengetahuan yang didapatkan di perguruan tinggi pada dunia kerja.

Hal itu dapat diwujudkan melalui proses pembelajaran dengan mengintegrasikan softskill dalam proses pembelajaran, salah satunya adalah menggunakan Edmodo untuk pembelajaran di kelas untuk mengetahui pengaruhnya terhadap softskill disiplin mahasiswa. Softskill disiplin merupakan suatu bentuk ketaatan terhadap aturan, baik tertulis maupun tidak tertulis. Selanjutnya, untuk mengukur tingkat disiplin belajar siswa diperlukan indikator-indikator mengenai disiplin, yaitu ketentuan disiplin waktu dan disiplin perbuatan/ tindakan (Moenir, 2010).

Tu'u (2004: 48) menyebutkan bahwa ada beberapa faktor disiplin, yaitu sebagai berikut: 1) kesadaran diri sebagai pemahaman diri bahwa disiplin dianggap penting bagi kebaikan dan keberhasilan dirinya, selain itu kesadaran diri menjadi motif kuat terwujudnya disiplin; 2) Pengikutan dan ketaatan sebagai langkah penerapan dan praktik atas peraturan-peraturan yang mengatur individunya; 3) Alat pendidikan untuk mempengaruhi, mengubah, membina, dan membentuk perilaku yang sesuai dengan nilai-nilai yang ditentukan atau diajarkan; 4) Hukuman sebagai upaya menyadarkan, mengoreksi dan meluruskan yang salah sehingga orang kembali pada perilaku yang sesuai dengan harapan. Sementara itu, Semiawan (2009) ada beberapa faktor lain lagi yang dapat berpengaruh pada pembentukan disiplin individu yaitu: (1) hubungan emosional yang kualitatif dan kondusif sebagai landasan untuk membentuk disiplin; (2) keteraturan yang konsisten dan berkesinambungan dalam menjalankan berbagai aturan; (3) keteladanan yang berawal dari perbuatan kecil dalam ketaatan disiplin di rumah, seperti belajar tepat waktu; (4) lingkungan yang berfungsi untuk pengembangan disiplin, baik lingkungan rumah, sekolah dan masyarakat. Karena itu, disiplin sangat penting terhadap kesuksesan seseorang. Sikap yang disiplin sangat berpengaruh terhadap ketercapaian/ kesuksesan pembelajaran di kelas.

Menurut Bruce (2013) Edmodo dapat menyebabkan siswa lebih berpartisipasi dalam pembelajaran, Edmodo merupakan alat yang perlu diperkenalkan kepada siswa karena lebih produktif dan memungkinkan siswa mudah dalam berinteraksi dalam dunia pendidikan. Lebih lanjut, setelah menggunakan Edmodo siswa memiliki sikap positif terhadap Edmodo, dan mereka berpikir bahwa itu adalah alat yang baik untuk meningkatkan pembelajaran siswa, peluang melalui partisipasi aktif dan komunikasi. Mereka ingin aktif di kelas dan mereka ingin mengembangkan hubungan yang hangat dengan instruktur melalui alat manajemen pembelajaran semacam ini (Uzun, 2015).

Penggunan Edmodo dapat diterapkan dalam pembelajaran dengan berbagai metode. Salah satunya adalah metode Blended Learning. Blended Learning merupakan model pembelajaran yang menggabungkan antara model pembelajaran tatap muka dengan model pembelajaran e-learning. Integrasi kedua model pembelajaran tersebut menawarkan kombinasi sinkron/ asinkron yang memenuhi kebutuhan belajar mahasiswa (Mozelius \& Hettiarachchi, 2017). Khoiroh, Munoto, \& Anifah (2017) mengungkapkan bahwa tujuan dikembangkannya Blended Learning adalah menggabungkan ciri-ciri terbaik dari pembelajaran di kelas (tatap muka) dan ciri-ciri terbaik pembelajaran online untuk meningkatkan pembelajaran mandiri secara aktif oleh peserta didik dan mengurangi jumlah waktu tatap muka di kelas. Penggunaan Edmodo dengan metode Blended Learning cukup baik memberikan/ mempengaruhi keterampilan mahasiswa dalam menggunakan fitur-fitur di Edmodo baik keterampilan membuat akun, menggunakan profil edmodo, quiz, assignment, note, maupun mengakses nilai (report) (Murjainah, 2019).

Hasil penelitian lain menyebutkan bahwa menggunakan Edmodo dapat meningkatkan minat dan hasil belajar pada materi kelarutan dan hasil kali kelarutan (Budhi, 2013). Lebih lanjut Afdhila, Nazar, \& Hanum (2017) mengungkapkan bahwa 
ketuntasan hasil belajar siswa dengan menerapkan model Blended Learning pada materi larutan penyangga sebesar $80,95 \%$ dengan kategori sangat baik.

Berdasarkan uraian tersebut, maka tujuan dalam penelitian ini adalah untuk mengetahui pengaruh pengunaan Edmodo dengan metode Blended Learning terhadap Softskill disiplin mahasiswa pendidikan geografi. Adapun, batasan permasalahan dalam penelitian ini adalah kedisiplinan mahasiswa dalam menyelesaikan tugas dengan menggunakan fitur tugas Edmodo yang ditujukan kepada mahasiswa yang mengikuti mata kuliah media pembelajaran geografi berbasis ICT.

\section{METODOLOGI PENELITIAN}

Metode penelitian yang digunakan dalam penelitian ini adalah penelitian kuantitatif. Metode kuantitatif merupakan metode ilmiah karena telah memenuhi kaidah ilmiah, konkret, terukur, rasional dan sistematis (Sugiyono, 2015).

Hipotesis dalam penelitian adalah:

Ha : Terdapat pengaruh yang signifikan penggunaan Edmodo dengan metode Blended Learning terhadap Softskill disiplin mahasiswa pendidikan Geografi.

Ho : Tidak terdapat pengaruh yang signifikan penggunaan Edmodo dengan metode Blended Learning terhadap Softskill disiplin mahasiswa pendidikan Geografi.

Kriteria pengujian hipotesis dalam penelitian ini adalah sebagai berikut:

- Terima Ho, bila $\mathrm{T}_{\text {hitung }} \leq \mathrm{T}_{\text {tabel }}$ berarti tolak Ha

- Tolak Ho, bila $\mathrm{T}_{\text {hitung }} \geq \mathrm{T}_{\text {tabel }}$ berarti terima Ha

Sampel yang digunakan dalam penelitian ini adalah mahasiswa yang mengikuti mata kuliah Media Pembelajaran Berbasis ICT di semester genap, yaitu kelas 4A. Teknik pengumpulan data yang digunakan adalah Dokumentasi dan angket.

Setelah data terkumpul data tersebut dianalisa dengan statistik untuk menguji normalitas data, menguji homogenitas data dan menguji hipotesis penelitian sebagai hasilnya nanti dapat diambil suatu kesimpulan guna membuktikan hipotesis penelitian. Uji normalitas dilakukan dengan menggunakan Spearman Brown dan uji hipotesis mengenai pengaruh yang signifikan dari penggunaan Edmodo dengan metode Blended Learning terhadap Softskill disiplin mahasiswa menggunakan Uji-t. Untuk menganalisis data perolehan dalam penelitian ini, analisis dilakukan dengan menggunakan tools berupa SPSS 16.

\section{HASIL DAN PEMBAHASAN}

Penelitian ini bertujuan untuk mengetahui pengaruh penggunaan Edmodo dengan metode Blended Learning terhadap Softskill disiplin mahasiswa pendidikan geografi. Penggunaan Edmodo dilakukan sejak pertemuan pertama hingga akhir. Penggunaan Edmodo ini dilakukan dengan menggabungkan pertemuan tatap muka dan online (Blended Learning) terutama dilihat dari kedisiplinan dalam mengerjakan tugas di Edmodo.

Dalam pelaksanaannya peneliti menggunakan Edmodo dengan membagikan materi, dan menggunakan fitur tugas Edmodo. Pemberian angket dilakukan setelah diberikan perlakuan kepada mahasiswa setelah menggunakan Edmodo, yaitu pada pertemuan petama dan pertemuan terakhir yakni, pertemuan ke-4 dalam penggunaan Edmodo. Setelah data diperoleh selajutnya dilakukan analisis dengan menggunakan Kolmogorov Smirnov dan uji $\mathrm{T}$ dengan menggunakan SPSS. Adapun hasil analisis dapat dilihat pada table berikut.

Tabel 1. Deskriptive Statistics

\begin{tabular}{|c|c|c|c|c|c|}
\hline & $\mathbf{N}$ & $\begin{array}{l}\text { Mini } \\
\text { mum }\end{array}$ & $\begin{array}{l}\text { Maxi } \\
\text { mum }\end{array}$ & Mean & $\begin{array}{c}\text { Std. Devia- } \\
\text { tion }\end{array}$ \\
\hline $\begin{array}{l}\text { Perlakuan } \\
\text { Awal }\end{array}$ & 37 & 9 & 20 & 13.46 & 2.775 \\
\hline $\begin{array}{l}\text { Perlakuan } \\
\text { Akhir }\end{array}$ & 37 & 14 & 20 & 17.62 & 1.754 \\
\hline $\begin{array}{l}\text { Valid N } \\
\text { (listwise) }\end{array}$ & 37 & & & & \\
\hline
\end{tabular}

Berdasarkan tabel 1 statistik deskriptif analisis dengan menggunaan SPSS tersebut, diketahui bahwa mean (rata-rata) untuk perlakuan awal sebesar 13,46 dengan nilai standar deviasi 
sebesar 2,775, nilai minimum sebesar 9 dan maksimum sebesar 20. Untuk perlakuan akhir diperoleh nilai mean (rata-rata) sebesar 17,62 dengan nilai standar deviasi sebesar 1,754 , nilai minimum sebesar 14 dan maksimum sebesar 20 . Ini menunjukkan terdapat perubahan antara perlakuan awal dan perlakuan akhir.
Selanjutnya, analisis uji normalitas data penelitian menggunakan uji normalitas Kolmogorov Smirnov yang bertujuan untuk membandingkan distribusi data (yang akan diuji normalitasnya) dengan distribusi normal baku. Hasil analisis kolmogorov smirnov dapat dilihat pada tabel 2 berikut.

Tabel 2. Uji Normalitas Kolmogorov Smirnov pada Kelas Sampel dengan Menggunakan SPSS 16

\begin{tabular}{|c|c|c|c|}
\hline & & Perlakuan Awal & Perlakuan Akhir \\
\hline \multirow{3}{*}{$\begin{array}{l}\text { Normal } \\
\text { Parameters }\end{array}$} & $\mathrm{N}$ & 37 & 37 \\
\hline & Mean & 13.46 & 17.62 \\
\hline & Std. Deviation & 2.775 & 1.754 \\
\hline \multirow{5}{*}{$\begin{array}{l}\text { Most Extreme } \\
\text { Differences }\end{array}$} & Absolute & .160 & .189 \\
\hline & Positive & .160 & .120 \\
\hline & Negative & -.137 & -.189 \\
\hline & Kolmogorov-Smirnov Z & .975 & 1.153 \\
\hline & Asymp. Sig. (2-tailed) & .297 & .140 \\
\hline
\end{tabular}

Sumber : Hasil analisis data, 2019

Berdasarkan tabel 2 tersebut, diketahui bahwa nilai signifikansi A siymp. Sig (2- tailed) untuk perlakuan awal sebesar 0,297 dan perlakuan akhir sebesar 0,140. Nilai Asiymp. Sig (2- tailed) tersebut lebih besar dari 0,05. Maka sesuai dengan dasar pengambilan keputusan dalam uji normalitas kolmogorov-smirnov di atas, dapat disimpulkan bahwa data perlakuan awal dan perlakuan akhir berdistribusi normal.

Dengan demikian, asumsi atau persyaratan normalitas dalam model regresi sudah terpenuhi.

Selanjutnya, uji homogenitas data penelitian dianalisis dengan menggunakan SPSS 16, dilakukan untuk mengetahui data yang dianalisis bersifat homogen/ sama. Hasil analisis data dengan menggunakan SPSS 16, dapat dilihat pada tabel 3 dan 4 berikut.

Tabel 3. Paired Samples Statistics

\begin{tabular}{|c|c|c|c|c|c|}
\hline & & Mean & $\mathbf{N}$ & Std. Deviation & $\begin{array}{c}\text { Std. Error } \\
\text { Mean }\end{array}$ \\
\hline \multirow[t]{2}{*}{ Pair 1} & Perlakuan Awal & 13.46 & 37 & 2.775 & .456 \\
\hline & Perlakuan Akhir & 17.62 & 37 & 1.754 & .288 \\
\hline
\end{tabular}

Tabel 4. Paired Samples Correlations

\begin{tabular}{llllll}
\hline & & N & Correlation & \multicolumn{2}{c}{ Sig. } \\
\hline Pair 1 & $\begin{array}{l}\text { Perlakuan Awal \& } \\
\text { Perlakuan Akhir }\end{array}$ & 37 & & .754 & .003 \\
\hline
\end{tabular}

Sumber : Hasil analisis data, 2019

Berdasarkan tabel 3 dan 4 tersebut, menunjukkan bahwa nilai korelasi antara 2

perlakuan tersebut dengan hasil 0,754 artinya terdapat hubungan kuat dan positif. Sedangkan, tingkat signifikansi hubungan menunjukkan hasil 
0,003 artinya terdapat signifikan 0,05 . Itu artinya, jika nilai signifikansi homogenitas $0,891>0,5$ maka dapat disimpulkan bahwa data penelitian bersifat homogen dan memiliki korelasi/ hubungan. Uji hipotesis dilakukan untuk menganalisis pengaruh penggunaan Edmodo dengan metode Blended Learning terhadap Softskill disiplin mahasiswa pendidikan geografi.
Agar dapat tercapainya tujuan tersebut, maka data yang diperoleh diuji menggunakan uji-t. Uji-t bertujuan untuk menguji generalisasi (signifikansi hasil penelitian berupa perbandingan keadaan variabel dari dua rata-rata sampel). Uji-t yang dilakukan dalam penelitian ini adalah dengan menggunakan SPSS 16. Hasil analisis uji-t dalam penelitian ini dapat dilihat pada tabel 5 berikut.

Tabel 5. Paired Samples Test

\begin{tabular}{llccrc}
\hline & & \multicolumn{3}{c}{ Paired Differences } \\
\hline & Mean & Std. Deviation & Std. Error Mean \\
\hline Pair 1 & $\begin{array}{l}\text { Perlakuan Awal - } \\
\text { Perlakuan Akhir }\end{array}$ & 4.162 & 3.640 & .598 \\
\hline
\end{tabular}

Sumber : Hasil analisis data, 2019

Pada tabel 5 tersebut, terlihat bahwa rerata 4,162. bernilai positif. Maka, berdasarkan analisis tersebut, menunjukkan terjadi kecenderungan peningkatan softskill disiplin mahasiswa setelah perlakuan.

Tabel 6. Paired Samples Test

\begin{tabular}{lccc}
\hline & \multicolumn{2}{c}{ Paired Differences } \\
\hline & 95\% Confidence Interval of the Difference \\
\hline & Lower & Upper \\
\hline Pair 1 & Perlakuan Awal - & 5.376 & 2.948 \\
& Perlakuan Akhir & & \\
\hline Sumber : Olahdata SPSS, 2019 & &
\end{tabular}

Tabel 7. Paired Samples Test

\begin{tabular}{llccr}
\hline & $\mathrm{t}$ & $\mathrm{df}$ & Sig. (2-tailed) \\
\hline Pair 1 & $\begin{array}{l}\text { Perlakuan Awal - } \\
\text { Perlakuan Akhir }\end{array}$ & 6.955 & 36 & .000 \\
\hline
\end{tabular}

Sumber : Hasil analisis data, 2019

Dilihat dari table tersebut, menunjukkan bahwa degree of freedom (derajat kebebasan) 36 dengan hasil uji $\mathrm{T}$ sebesar 6,955. Bila dibandingkan dengan $\mathrm{t}$ tabel pada $\mathrm{DF} 36=$ 1,68830. Maka $t_{\text {hitung }}(6,955)>t_{\text {tabel }}(1,68830)$. Kemudian, dilihat dari signifikansi (2-tailed) dengan nilai probabilitas $/ \mathrm{p}$ value uji $\mathrm{T}$ Paired menunjukkan hasil $=0,000$ dan nilai $\mathrm{p}$ value $(0,000)>0,05$ (95 \% kepercayaan). Maka berdasarkan hasil analisis tersebut dapat disimpulkan bahwa terdapat pengaruh yang signifikan antara sebelum dan sesudah perlakuan. Dengan demikian, terdapat pengaruh yang signifikan dari penggunaan Edmodo dengan metode Blended Learning terhadap Softskill mahasiswa pendidikan geografi.

Ini sejalan dengan penelitian Daulay, Syarifudin dan Manurung (2016) menunjukkan bahwa (1) Terdapat pengaruh blended learning berbasis Edmodo terhadap hasil belajar IPA 
biologi siswa kelas VIII SMP Negeri 5 Medan; (2) Terdapat pengaruh blended learning berbasis Edmodo terhadap retensi belajar siswa kelas VIII SMP Negeri 5 Medan; (3) Terdapat pengaruh motivasi belajar terhadap hasil belajar IPA biologi siswa kelas VIII SMP Negeri 5 Medan; (4) Terdapat pengaruh motivasi belajar terhadap retensi belajar siswa kelas VIII SMP Negeri 5 Medan; (5) Terdapat interaksi antara blended learning berbasis Edmodo dan motivasi terhadap hasil belajar IPA biologi siswa kelas VIII SMP Negeri 5 Medan; (6) Terdapat interaksi antara blended learning berbasis Edmodo dan motivasi terhadap retensi belajar siswa kelas VIII SMP Negeri 5 Medan.

Penggunaan model pembelajaran Blended Learning berbasis Edmodo ini efektif dikarenakan Edmodo memiliki beberapa keunggulan yaitu: (1) mengadaptasi tampilan seperti facebook secara sederhana, sehingga membuat mahasiswa lebih termotivasi untuk belajar; (2) Edmodo mendukung preview berbagai jenis format file; (3) Edmodo tidak hanya dapat diakses dengan menggunakan PC (laptop / desktop) tetapi juga bisa diakses dengan menggunakan gadget berbasis Android atau iOS (Susilawati, 2018).

\section{SIMPULAN}

Setelah dilaksanakan pembelajaran melalui penggunaan Edmodo dengan metode blended learning menunjukkan bahwa terdapat pengaruh terhadap softskill disiplin mahasiswa pendidikan geografi yang ditujukkan dengan $t$ tabel pada DF $36=1,68830$. Maka $t_{\text {hitung }}(6,955)>t_{\text {tabel }}(1,68830)$ dan signifikansi (2-tailed) dengan nilai probabilitas/p value uji $\mathrm{T}$ Paired menunjukkan hasil $=0,000$ dan nilai $\mathrm{p}$ value $(0,000)>0,05(95$ $\%$ tingkat kepercayaan).

\section{Ucapan Terimakasih}

Terimakasih

$$
\text { kepada }
$$

DRPM

Kemenristekdikti atas pendanaan hibah Penelitian Dosen Pemula tahun pendanaan 2019.

\section{DAFTAR PUSTAKA}

Afdhila, R., Nazar, M., \& Hanum, L. (2017). Penerapan Pembelajaran Blended Learning Pada Materi Larutan Penyangga di SMA Negeri 1 Unggul Darul Imarah. Jurnal Ilmiah Mahasiswa Pendidikan Kimia (JIMPK) Vol 2 No 3, 165-172.

Bruce, K. (2013). How Edmodo into a High School Service Club: To Promote Interactive Online Communication. . 18Th TCC Worldwide Online Conference. USA.

Budhi, J. (2013). Penerapan Blended Learning dengan Number Heads Together untuk Meningkatkan Minat dan Prestasi Belajar pada Materi Kelarutan dan Hasil Kali Kelarutan Siswa Kelas XI IPA 1 SMAN Gondangrejo Tahun Ajaran 2012/2013. Jurnal Pendidikan Kimia, II (4), 96-101.

Daulay, U. A., Syarifuddin, \& Manurung, B. (2016). Pengaruh Blended Learning Berbasis Edmodo dan Motivasi Belajar Terhadap Hasil Belajar IPA Biologi dan Retensi Siswa pada Sistem Peredaran Darah Manusia di Kelas VIII SMP Negeri 5 Medan. Jurnal Pendidikan Biologi, Vol.6 No.1 Edisi Desember.

Khoiroh, N., Munoto, \& Anifah, L. (2017). Pengaruh Model Pembelajaran Blended Learning dan Motivasi Belajar Terhadap Hasil Belajar Siswa. Jurnal Penelitian Ilmu Pendidikan Vol. 10 No.2, September, 97-110.

Manara, M. (2014). Hard Skills dan Soft Skills pada Bagian Sumber Daya Manusia di Organisasi Industri. Jurnal Psikologi Tabularasa Vol.9 No.1, April, 37-47.

Moenir. (2010). Masalah-Masalah dalam Belajar. Yogyakarta: Bumi Aksara.

Mozelius, P., \& Hettiarachchi, E. (2017). Critical Factors for Implementing Blended Learning in Higher Education. ICTE Journal, 6(1) , 418.

M Murjainah. (2019). Keterampilan Mahasiswa Pendidikan Geografi Dalam Menggunakan Edmodo Berbasis Blended Learning. . 
Prosiding Seminar Nasional Pendidikan FKIP p-ISSN 2620-9047, e-ISSN 2620-9071 (pp. 389-401). Serang: Universitas Sultan Ageng Tirtayasa.

M Murjainah, \& Utomo, B. (2018). Pengaruh Praktikum Sistem Informasi Geografis Terhadap Kemampuan Mahasiswa Pendidikan Geografi Dalam Membuat Peta Berbasis Arcgis . Jurnal Swarnabhumi Vol.3 No.1, Februari.

Semiwawan, C. (2009). Kreativitas Keberbakatan. Jakarta: Pt. Indeks.

Sugiyono. (2015). Metode Penelitian Pendidikan. Bandung: Alfabeta.
Susilawati. (2018). . Pengaruh Model Pembelajaran Blended Learning Berbasis Edmodo Terhadap Hasil Belajar Mahasiswa . Jurnal Edutech Vol.17 No.2.

Tu'u, T. (2004). Peran Disiplin pada Perilaku dan Prestasi Siswa. Jakarta: Grasindo.

Uno, H. (2008). Orientasi Baru dalam Psikologi Pembelajaran. Jakarta: Bumi Aksara.

Uzun, E. (2015). Students's Attitude Towards Edmodo as a Supplementary Tool for Higher Education. Participatory Educational Research (PER) Special Issue ISSN : 21486123, 78-83. 